\title{
"The Name Flows from the Naming": The Key to Understanding Medbh McGuckian’s Poetry
}

\author{
Shane Alcobia-Murphy \\ University of Aberdeen
}

Copyright (c) 2008 by Shane Alcobia-Murphy. This text may be archived and redistributed both in electronic form and in hard copy, provided that the author and journal are properly cited and no fee is charged for access.

\begin{abstract}
The purpose of this article is to demonstrate how a reading of Martin Heidegger's philosophy might illuminate McGuckian's work and to examine the ways in which it helps to define (and affirm) it as poetry. Based on original research into the sources of McGuckian's poems, I want to argue that her texts often declare their status as poetic texts, that an uncovering of her intertextual borrowings can aid in the grasping of their "cognitive import", and that the intertexts themselves suggest interpretative frameworks for analysing the poetry.
\end{abstract}

Key Words. McGuckian, Heidegger, intertextuality, poetry, reception

Resumen. Este artículo propone demostrar que una lectura de la filosofía de Martin Heidegger puede arrojar luz sobre la obra de McGuckian, así como examinar las maneras en que ayuda a definirla (y afirmarla) como poesía. Basándome en investigaciones inéditas sobre las fuentes de los poemas de McGuckian, sustento que sus textos a menudo definen su estatus como textos poéticos, que al desvelar los préstamos intertextuales se ayuda a captar su "relevancia cognitiva", y que los propios intertextos sugieren marcos interpretativos para analizar la poesía.

Palabras clave. McGuckian, Heidegger, intertextualidad, poesía, recepción

I have nothing to say. I am saying it and that is poetry. (Cage, 1973: 109)

It is by now a critical commonplace to describe Medbh McGuckian's poetry as "obscure", a term rarely used in approbation with regards to her oeuvre. Accurately summarising the current critical consensus, Rui Carvalho Homem writes that "[f]ew contemporary poets with well established careers and nearcanonical status will have been so hounded by one single critical topos as Northern Irish poet Medbh McGuckian. That topos concerns her supposed obscurity, mentioned vociferously, dismissively, apologetically, or with some enthusiasm, depending on the critical perspective and on the ensuing degree of sympathy" (2006: 187). Her poetry continues to be read as "private and inward-turning, nonrational, built upon the inaccessible logic of dream and subconscious associations" (Skloot, 2004: 150). With the texts' supposedly "indiscriminate syntax", the reader is faced with "a language functionally indiscriminate: a poetry knot, a poetry clot" (McDaniel, 2006: n.p.). In short, "we are given images but no compass” (Burgan, 2004: n.p.). Thus, as a writer, McGuckian is often written off by reviewers as having produced "a lyrical concoction which seems intentionally evasive of ultimate 'meaning'” (O’Grady, 1999: n.p.). Such a negative reception seems to stem from the reviewers' inability to discern a clear, 
coherent rationale behind her work. The purpose of this article is to demonstrate how a reading of Martin Heidegger's philosophy might illuminate McGuckian's work and to demonstrate the ways in which it helps to define (and affirm) it as poetry. While poetry in the weak sense - or what Martin Heidegger terms ordinary naming (eindeutig) (Heidegger, 1977: 15) - makes use of language as a means for unambiguous information exchange, McGuckian's work will be seen in the strong sense: it is "language in itself and not the arbitrary individuality of the poet that really speaks in the poem” (Pattison, 2000: 169). As such, hers can be viewed as an example of poetic naming (vieldeutig):

If we are to use 'vieldeutig' to understand the essence of poetry we must, says Heidegger, decompose the term into its literal meaning: 'of many things', possessed of a 'multiplicity' or 'richness in meaning'. For to every 'genuinely' poetic word belongs an 'inexhaustible' range of 'complex spaces of [semantic] vibration (vielfältige Schwingungsräume)', from which it follows that, unlike the word of (at least ideal) information exchange, the poetic word has no 'definition'. It communicates, means, more than can ever be captured in words, is, to use a familiar word from the philosophy of art, unparaphrasable. (Young, 2001: 103)

While poetry as a singular linguistic construct is one that "overreaches the selfunderstanding of the poet, that is irreducible to the personal and communal circumstances of its production and inexplicable in terms of psychology, logic or philosophy" (Pattison, 2000: 170), it does not follow that as readers we ought to side-step the issue of comprehensibility and assert that "her poetry only becomes difficult if the reader attempts to find meaning, and tries to intellectualize her writing” (Burgoyne-Johnson, 1999: 1); rather, as Julian Young notes with regard to Heidegger's conception of vieldeutig, to argue that "information transference is not the point of poetry" is "not the same as saying that poetry lacks 'cognitive import”" (2001: 103). Of course, since the interpretations which follow constitute a paraphrastic rephrasing of the poetic texts, they will run the risk of doing violence to them: they will put "in other words what the poet could only have said poetically" (Froment-Meurice, 1996: 11). However, there is too much at stake here to avoid the attempt at providing at least a glimpse at the rationale behind McGuckian's poems; as Patrick Grant has put it, "the future reputation of McGuckian's work as a whole might well depend on whether or not the critical consensus is that she provides mainly alluring enigmas [...] or that there is a key to these enigmas, releasing a coherence that readers find illuminating and not just arbitrary" (2001: 94).

In previous work I have unearthed many sources which lie behind McGuckian's work and have demonstrated how an uncovering of her intertextual borrowings can aid in the grasping of their "cognitive import". Indeed, the intertexts themselves often suggested interpretative frameworks for analysing the poetry. ${ }^{1}$ In what follows, I want to argue that McGuckian's texts often declare their status as poetic texts and that her use of Heidegger, in particular, can provide the compass with which to best appreciate her images. This does not mean that her work is any the less oblique since it still requires considerable scholarly effort to unearth the sources; nevertheless, an analysis of how she uses Heidegger counteracts claims that her work is somehow irrational and meaningless.

The very title of McGuckian's “The Selfconcealing" (2003: 87) pointedly alludes to the text's dislocation of narrative voice; it initiates what Danielle Sered terms a "radical [...] disruption of a traditional concept of authority": what we perceive is the "animation of $[\ldots]$ the speaking voice, an opening up of the text to endless proliferations, and an absent - or at least different - lyric centre" (2002: 273). The second and third stanzas express, through the related tensions of multivocality/single voice and sound/silence, the correlative conflict that arises from a venture that imbricates borrowed textual fragments within a lyric poem: what supposedly "ring out", or sound vigorously, are the dispersive "voices" and not the author's distinctive voice, whose "ownmost self" is shielded. Yet McGuckian's poetry disrupts this opposition: while clamorous, the "ringing out of voices" is not discordant, and as readers we do not perceive "the silent voice / of this joining" to be dissonant; rather, the author's characteristic voice is constituted by the weaving together of the unperceived and unattributed voices. Structurally, the poet

1. See Alcobia-Murphy, Sympathetic Ink (2006). 
conveys the seamless nature of her enterprise through thematically apt enjambments: firstly, between the stanzas (a structural "joining”); and secondly, between the opening lines of the third stanza (initiating its own "flow"). Indeed, the stanza-break itself intimates the silent voice being described, graphically represented as it is by the liminal white space over which the reader's eye must pass:

not only through a ringing out
of voices (202)
Only with the greatest difficulty
can we hear the silent voice
of this joining (203)
And the name flows from the naming (215)
more willingly beauty
dwells on earth (204)
spares its appearing (203)

Not only through a ringing out of its voices, but with the greatest difficulty can we hear the silent voice of this joining. The name flows from the naming, and more willingly beauty dwells on earth, but spares

its appearing, as its ownmost self.

McGuckian's poem is made up of carefully selected quotations from Heidegger's Elucidations of Hölderlin's Poetry, ${ }^{2}$ a series of essays which, steeped in an idiosyncratic Graecocentrism, lament the departure of the gods and depicts the modern epoch as characterised by alienation, meaninglessness and nihilism: "In the dis-enchanted world of Gestell, the age in which, as resource, everything 'obtrude[s] and accumulates in a dry, monotonous and therefore oppressive [claustrophobic] way', nothing at all stands forth, for modern man, as holy and so, in particular, the names of the gods fail to do so" (Young, 2001: 90). In an age where human beings treat one another as "consumers" and "human resources", Heidegger turns for salvation to poets, "the authentic few who, remembering the past, are truly alive to the desolation of the present” (Young, 2001: 74).

2. Heidegger, 2000. Citations from Heidegger are cited here on the left of McGuckian's text.
McGuckian's poem constitutes a concise gloss on, and affirmative restatement of, Heidegger's thesis; it is a poetic manifesto, a deeply serious avowal of poetry's role and power, and one that upholds the belief that in "poetic meaning [...] we experience the 'self-secluding' in things, the infinitude, the unfathomability, the 'secret' life that belongs to every being", that "in its naming the holy shows itself” (Young, 2001: 104).

The two stanzas cited above envisage poetry as "the deepest revelation of what is" and project a way of breaking free from "the grip of technologically oriented thinking" (Pattison, 2000: 162), and are written in answer to a question posed in the preceding stanza:

But to where could we step back? (202)

this destiny of denial (202)

its fourfoldedness (203)

encircles the globe (202)

To where could we step back

from this destiny of denial

whose fourfoldedness

encircles the globe?

The "fourfoldedness" is the ideal unity, "the fourfold of earth, sky, mortals and gods" (Pattison, 2000: 160), one which modern man cannot achieve because he no longer has an originary encounter with the world; as Heidegger states, "[t]he appearing of the infinite relation as a unified whole remains denied to us" (2000: 202). Caught within "this destiny of denial", the poet asks "to where could we step back"? Heidegger's answer is enigmatic: "Into the awaiting reserve. This is at the same time the supposing which thinks in advance. Such reserve anticipates what is coming, in that it attempts to experience what is present" (2000: 202). To understand what the German philosopher means here, and to comprehend the role that he conceives poetry as playing, we must look more closely at the quotations that McGuckian uses in the second stanza which both diagnose the ills of modern society and offer a prescription:

It is the center of the whole infinite relation. It is pure destiny itself. What is uncanny encircles the globe now that destiny strikes the men of this age directly, not only through a ringing out of its voices. Destiny approaches man silently a mysterious kind of stillness. Thus, he is still unable to correspond to this destiny of denial. 
Rather, he evades it through his more and more hopeless attempts to master technology with his mortal will.

As soon as we trouble ourselves to reflect on this, a supposition arises: the ordering of a joint may hold sway within the power of that provocation, that is, within the absolute, essential domination of modern technology, from which and through which the whole infinite relation joints itself into its fourfoldedness. Only with the greatest difficulty can we hear the silent voice of this joining. For in preparation for this listening, we must first learn again to hear an older saying, in which the once great destiny of Greece rang out. (2000: 202-3, emphases added)

To counteract a world that is led by a nihilistic, yet all-encompassing, belief in the primacy of scientific technology, Heidegger proposes art (Dichtung) as a means of illuminating the ordinary, of ripping "us for a time out of the ordinary into another world" (Inwood, 1997: 111). Championing this poetic use of language, he contends that "[b]eauty is truth experienced in a Greek way, namely, the unconcealing of what comes to presence by its own power, of $\varphi v$ $\sigma ı \varsigma$ that nature in which and from which the Greeks lived" and that art "as the pointing that allows the appearance of what is invisible, is the highest kind of showing" (2000: 185, 186). "For Greek thought," says Heidegger in "The Origin of the Work of Art", "the essence of knowing consists in alètheia, that is, in the revealing of beings" (1993: 184), and it is poetic language that acts as the mode of unconcealment, a projective saying, "a bringing forth of beings in that it brings forth what is present as such out of concealment and specifically into the unconcealment of its appearance” (1993: 184). As a title, then, "The Self-concealing" refers directly to that "older saying" in which "the once great destiny of Greece rang out", echoing as it does Heraclitus' Fragment 54 which declares: "The joint that denies its appearance is of a stronger ruling than the one that comes to appearance" (Heraclitus in Heidegger, 2000: 203). Glossing this phrase, Heidegger states that it intimates how "we must experience all Greek beings, nature, men, human works, and the divinity; everything visible in terms of the invisible everything sayable in terms of the unsayable everything which appears in terms of the selfconcealing” (2000: 206-7). Thus, the title not only meta-poetically alludes to the selfconcealment that consequentially arises from McGuckian's strategic arrangement of intertexts within her poems, it also refers directly to the Heideggarian notion that "[p]oetry is the saying of the unconcealment of beings" (2000: 198). When she cites Heidegger as saying that "the name flows from the naming", she is thus referring to the idea that naming "unveils, reveals", that poetry is a "showing that discloses what and how something is to be experienced and preserved in its presence" (2000: 215). Hence, quoting directly from Hölderlin's "Greece”, she is able to contend that, with the poet as mediator between man and the gods, "more willingly / beauty dwells on earth" (Hölderlin in Heidegger, 2000: 204).

Now, now words for it (214)

the eyelids of those eyes

the eyes' blue school (190).

whose school is the blue of heaven (194)

Now, now, words for it, the eyelids of those eyes, the eyes' blue school, whose school is the school of heaven.

In Heidegger's commentary on Hölderlin, the singer's voice is said to call out to heaven, looking for immortality. Yet the gods are reconciled to their concealment - they "cover the eyelids with art", "the eyelids whose school is the blue of heaven" (2000: 194). The poem's opening cites a well-known line from Hölderlin's "Bread and Wine" which, in context, suggests that, since man is "incapable of openly and directly receiving" the gods' presence, he must be resigned to "bearing one's burden": he must wait for the words to be found and to blossom (2000: 214):

Such is man; when the good is there, and a god himself

Cares for him with gifts, he neither knows it nor sees it.

First he must suffer; but now he names his most loved,

Now, now words for it, like flowers, must spring to life.

Yet the same line, transplanted to "The Selfconcealing”, becomes both declarative and affirmative: for this poet, the words are now blossoming. Hence, at the poem's conclusion, she can declare that immortality is conferred: 
Insofar as death comes, it vanishes (190)

death is also a life (189)

Insofar as death comes, it vanishes, and whether it comes from afar, it is also a life.

McGuckian's text has named the names; its projected saying finally breaks the "destiny of denial".

The importance of Heidegger's conception of poetry for McGuckian can hardly be overstated as he is one of the few exemplars to whom she returns in subsequent texts. In "Four Voices without an Instrument” (2004: 19-20) she again presents a manifesto on poeisis and the poet's status using textual fragments borrowed from the German philosopher. The title, however, is a quotation from a letter written by the composer Felix Mendelssohn to his sister, Fanny, commenting on his proposed settings of Heine's Volkslieder (1839): in a departure from his more usual piano/voice arrangement, he intends to set them to " "four voices without an instrument'” (MercerTaylor, 2000: 132).

According to Mendelssohn's biographer, Mercer-Taylor, this constituted a move away from the "Romantic instincts of his youth" and towards "the Biedermeier", a type of art which was "embraced as the embodiment of all that was insufferably decorous, comfortable, complacent and respectable in the conservative culture of the decades following the Napoleonic wars" (2000: 131-2). One could well conclude that, with such a title, McGuckian is playing into the hands of those who wish to dismiss her own work as "merely arch", "maddeningly fey", "insubstantial” and "irritatingly whimsical” (Lucas, 1988: 38). Yet the title does have a more immediate relevance for the poem, referring, in part, to the "four voices" in her text - her own, Heidegger's Elucidations of Hölderlin's Poetry, Oliver Taplin's edited collection of essays entitled Literature in the Greek and Roman World, and Peter Mercer-Taylor's biography of Mendelssohn ${ }^{3}$ - and it is in the weaving together of such voices that we find an insistent poetic credo.
In the month of March $(\mathrm{H}, 103)$

temperature had been further raised (Taplin 107)

a self-opening $(\mathrm{H}, 79)$; in mourning $(\mathrm{H}, 80)$

the becoming-light $(\mathrm{H}, 80)$

The northeast wind $(\mathrm{H}, 103)$

Reading the quarters of the sky $(\mathrm{H}, 111)$

When day and night are equal $(\mathrm{H}, 103)$

Another March month has come

to raise the temperature of the world, a self-opening, clear, in mourning, becoming light.

The northeast wind

reads the quarters of the sky

where the moon falls awake

into its own mouth

till day and night are equal.

The poem's opening stanzas depict the anticipated primaveral relief from a bleak winter's darkness: spring brings welcome light and life to the world. However, it is "another" March month not only because of the calendric certainty of its recurrence, but also due its poetic return in the form of a quotation from Hölderlin's "Remembrance”: "The northeast blows, / Of winds the dearest / To me [....] In the month of March, / When day and night are equal” (Hölderlin in Heidegger, 2000: 103). "March" in this context refers to the beginning of the Greek festivals, or holidays in the original sense of "holy-days". On a "Feiertag", says Heidegger, "we "step into the ... intimation of the wonder (Wunder) that around us a world worlds all, that there is something rather than nothing, that there are things and we ourselves are'” (Heidegger cited in Young, 2001: 86). Yet everything is held in a liminal stasis in the poem at this point: March is the transitional month, promising "the reconciliation between the harshness and sternness of winter and the ease and force of summer" (Heidegger, 2000: 132); nature ( $\Phi v \sigma l \varsigma)$ is depicted as "an emerging and an arising, a self-opening, which, while rising, at the same time turns back into what has emerged, and so shrouds within itself that

3. The poem is made up of quotations from Heidegger (2000 - referred to as " $\mathrm{H}$ " in the offset quotations), Taplin (2000) and Mercer-Taylor (2000). Citations from these texts are cited here on the left of McGuckian's text. 
which on each occasion gives presence to what is present” (Heidegger, 2000: 79).

Nature may be awake, becoming light, but she is said to be "awake in the manner of mourning”. Mourning, argues Heidegger, "withdraws from everything into the memory of one thing only. The remembrance of mourning remains near to what has been taken from it and seems to be distant" (2000: 77). What is being mourned, or remembered, is the presence of the gods (or rather, their present distance). Using the present continuous tense and a clever enjambment, McGuckian's text balances transition with stasis: nature is "in mourning / becoming light". This sense is reinforced by representing day and night as being equal. So how can the world emerge fully from its darkness, from its mourning?

The "northeast wind", significant, of course, due to McGuckian's domicile in Belfast, is said to be "the wind [...] which in the poet's homeland brightens up 'the air' [...] and extends gaiety into the distance" (Heidegger, 2000: 109). The pervasive imagery of brightening is all-important here since, being alienated from the "holy 'fire'”, man's task in a modern world characterised by spiritual destitution is said to be "the opposite of the Greeks"”, that is, "to recover the 'fire'” (Young 2001: 97). Who exactly can achieve such a task? The answer is, unsurprisingly, the poets. The northeast wind is said to set the mariners in Hölderlin's "Remembrance" on their travels, and these sailors are read by Heidegger as figures of the poet: "They say the holy. They must therefore know the heavenly bodies and be masters in reading the quarters of the sky" (Heidegger, 2000: 111). To where are these poets-mariners voyaging, and what draws them there? In fact, their journey to a foreign land is, in essence, a homecoming. "In this preference for the northeast," says Heidegger, "there reigns the love for the experience of the fiery spirit in the foreign land. The love for what is not like home, purely for the sake of becoming at home in what is one's own, is the essential law of destiny by which the poet is sent into the foundation of the history of the 'fatherland'” (Heidegger, 2000: 111-2). Such a statement makes for uncomfortable reading given Heidegger's past affiliation with the German fascist regime in the 1930s, but when he says, commenting on Hölderlin's text, that the northeast wind "'calls' the poets to find themselves in the destiny of their historical being”, it does not pertain to matters solely Deutsch; rather, it is a further call for poets to act as mediators between the gods and man.

The journey, simultaneously to a foreign land and homeward, is neatly suggested in stanza three of McGuckian's poem:

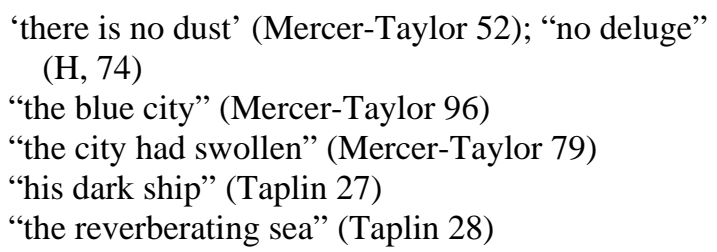

There is no dust, no deluge.

The blue of the city has swollen or returned to itself

in its dark ship

the reverberating sea.

The extracts taken from Literature in the Greek and Roman World come from the editor's own essay entitled "The Spring of the Muses", a title which is directly linked to the thematics of McGuckian's text. Indeed, the essay begins with a crucial image which pervades "Four Voices without an Instrument", that of sunrise: "The rosy fingers which heralded the extraordinary era we know as 'ancient Greece' first gradually spread between 900 and 700 BCE" (Taplin, 2000: 22). The specific quotations taken from Taplin's text are from a passage where he is quoting Hesiod's Works and Days to tell of how that poet's father changes his livelihood from agriculture for a life on the sea, "quitting Kyme in Aiolis, all the way in a dark ship" (Taplin, 2000: 27, my italics). Like the mariners in Hölderlin's "Remembrance", the father is compelled to undertake a journey to an unfamiliar territory. ${ }^{4}$ What then follows is a section on seafaring in which Hesiod states: "I shall show you the measures of the reverberating sea, / Uninitiated though I am in the skills of seamanship and boats" (Taplin, 2000: 28, my italics). The journey's trajectory, however, is homeward: the city figured in McGuckian's poem returns "to itself”. To illustrate this, the stanza depicts a second artist journeying southward: Mendelssohn travels to Italy in 1831 and describes Florence in a letter as "the blue city" (Mercer-Taylor, 2000: 96). Yet that foreign

4. See Taplin, 2000: 28. 
territory is conjoined in the poem with the Mendelssohn family home at 3 Leipzigerstrasse, a magnificent, idyllic and enclosed plot: "there is no dust” because “one doesn't hear any carriages or see anyone” (Mercer-Taylor, 2000: 52).

In the following stanza, the poet registers the fear that "Even the light ... would never be allowed its brightness". This refers to Heidegger's commentary on Hölderlin's poem "Homecoming": having described how the angels, the "messengers of gaiety", greet the poet, the philosopher contends that the poem describes how, "above the light, gaiety itself opens itself up into its pure brightening, without which even the light would never be allowed its brightness" (2000: 37). While McGuckian is initially afraid that such gaiety will not come to pass, the remaining stanzas reaffirm her faith in poetic speech:

"Since we have been a conversation" $(\mathrm{H}, 56)$

"three-in-one” $(\mathrm{H}, 38)$

"this sign has become my chosen one" $(\mathrm{H}, 61)$

"a garden, which is itself surrounded by

other gardens” (Mercer-Taylor, 52)

"houses those times we call the seasons" $(\mathrm{H}, 36)$

“their lives may have overlapped” (Taplin 27)

"the musicians actually blew out their candles

And left the stage one by one” (Mercer-Taylor 141)

"the sunburst of winds" (Mercer-Taylor 117)

“on their lowest strings” (Mercer-Taylor 202)

"Not without wings" ( $\mathrm{H}, 134)$

"When the mists vanish" $(\mathrm{H}, 109)$

"the brightening earth is the first angel" $(\mathrm{H}, 35)$

"first 'angel of the year"” $(\mathrm{H}, 36)$

Yet since we have been a conversation, the three-in-one sign

of your stained-glass voice

has become my chosen one,

a garden surrounded by other gardens,

housing the seasons.

Though our lives may have overlapped the musicians that blew out their candles and left the stage, one by one,

now blow for me

a sunburst of winds

on their lowest strings;

so that not without wings, when the mist vanishes, the brightening, endangered earth is the year's first angel.
These final stanzas bring together the poem's key strands of imagery, each suggestive of completed transitions: movement from one season to another; the journey home; the visitation of the muse/gods/angels. The poet is "at home" in two senses: physically, since the description refers to the secure and peaceful surroundings of 3 Leipzigerstrasse (" A whole row of rooms opens on to a garden, which is itself surrounded by other gardens'” [MercerTaylor, 2000: 52]); and spiritually, since she has experienced that which is unheimlich. " "The year", says Heidegger, "houses those times we call the seasons", and at this juncture we have moved to Spring: "the brightening light is the first 'angel of the year"” (2000: 36). The figure of the angel is appropriate here given that McGuckian's collection, The Book of the Angel, is an examination of the role played by angels in religion and literature. In Greek, "messenger" can be translated as "angel”, and this also links him to Hermes, the god of the paths and Heidegger's god of hermeneutics. ${ }^{\mathbf{5}}$ The poet in McGuckian's text has journeyed over the paths towards home, only with the aid of the messenger. As Heidegger comments with reference to Hölderlin's “The Ister”, “the paths name the transition for passing over to the other side. Not without wings may ... one cross over from the side of the foreign to the side of home" (2000: 134). Those “wings" belong to the angel which appears here in the form of "the brightening light", glossed by Heidegger as "the first 'angel of the year"” (2000: 36). The "three-in-one sign" not only connotes three exemplars within a single text - HeideggerMercer-Taylor-Taplin or Hölderlin-HesiodMendelsshon - but also refers to the necessary conjunction of earth, light and god which brings gaiety to the poet: "The joyful one and the joyful messengers of the brightening, father aether, and the angel of the house (the earth), and the angel of the year (light), cannot accomplish anything by themselves. Indeed, among all those who dwell within the orbit of gaiety, these three-in-one are loved the most by those who rejoice" (2000: 38). The "sign" may also refer to that which signifies the god's presence. Writing to a friend prior to his final journey to France, Hölderlin tells of his joy at

5. See Froment-Meurice, 1996: 22-3. 
beholding the symbol of heavenly fire: "I am pleased as when in the summer "the old holy father with calm hand shakes the holy lightning flashes out of the red clouds'. For among all that I can see of God, this sign has become my chosen one”" (Heidegger, 2000: 61).

In "Four Voices without an Instrument", the poet self-reflexively comments on the influence on her of her exemplars: having been in "conversation" with them, they become her "stained-glass voice". They have become her muses, her visiting angels, and they help her affirm her own belief in poetic language (in the Heideggarian sense). Man's being, for the German philosopher, "is grounded in language"; however, he argues, "this actually occurs in conversation" and "since language has authentically come to pass in conversation", the gods are said to "have come to expression and a world has appeared" (2000: 57). The stanza in which McGuckian mentions this "conversation" is made up of quotations which speak of enabling influences. The first extract comes from Taplin's essay which talks of how the lives of Homer and Hesiod "may have overlapped", how they may have been contemporaries and may have participated "in the same poetic occasions" (2000: 27). The second refers to Mendelssohn's "advocacy of older music", particularly in his 1838 series of four "Historical Concerts". During the second of these concerts, which closed with Hayden's "Farewell” Symphony, "the musicians actually blew out their candles and left the stage one by one” (Mercer-Taylor, 2000: 141). The third extract also comes from Mercer-Taylor's biography, referring to Mendelssohn's selfquotation in his Italian Symphony in which "the sunburst of winds with which the piece begins is lifted more or less directly from a colouristic wash early in the 'Prosperous Voyage' [an earlier piece]'” (2000: 117). Appropriately, the stanza as a whole constitutes a plea for influence: while her exemplars' work has been completed and may be rooted in the past, she asks for the musicians "to blow for me". The sound produced is a curious hybrid of the melancholic and the uplifting: she asks for the cheerful "sunburst of winds" to be played on "the lowest strings", referring here to the second movement scherzo from Mendelssohn's String Quartet in F-minor from 1847 which features the "cheerless, dark-hued trio (the cello, viola and second violin spend nearly the entirety of the trio on their lowest strings)" (Mercer-Taylor, 2000: 202). That double-edged sound is apt given that the earth in her final stanza is described as both "brightening" and "endangered": while poets like McGuckian may act as messengers of the gods to affirm the "fourfold unity", the earth is still in thrall to their "destiny of denial".

Perhaps the foregoing analyses of McGuckian's texts confirm that her poetry is "obscure" since the references are all unattributed and it requires scholarly effort to trace the allusions. However, what cannot be denied is that there is a clear rationale behind these poems and that they constitute not only intense negotiations with past art, but also a deeply felt belief in the primacy (and efficacy) of poetry in the modern world. Such analyses ought to prompt critics to look more closely at McGuckian's texts and perhaps read them in light of Heidegger's philosophy.

\section{Works Cited}

Alcobia-Murphy, Shane. 2006. Sympathetic Ink: Intertextual Relations in Northern Irish Poetry. Liverpool: Liverpool University Press.

Bugan, Carmen. 2004. “The Land Within”. Times 8 October 2004. Accessed online Burgoyne-Johnson, Jolanta. 1999. Bleeding the Boundaries: The Poetry of Medbh McGuckian Coleraine: Cranagh Press.

Cage, John. 1973. “Lecture on Nothing”. Silence. London: Calder and Boyers.

Froment-Meurice, Marc. 1996. That Is to Say: Heidegger's Poetics. Stanford: Stanford University Press.

Grant, Patrick. 2001. Literature, Rhetoric and Vilence in Northern Ireland, 1968-98: Hardened to Death. Basinstoke: Palgrave.

Heidegger, Martin. 1977. Martin Heidegger: Gesamtausgabe. V. 52. Ed. F.W. von Herrmann. Frankfurt-onMain: Klostermann. 
2000. Elucidations of Hölderlin's Poetry. Trans. Keith Hoeller. New York: Humanity Books.

Homem, Rui Carvalho. 2006. “Looking for Clues: McGuckian, Poems and Portraits”.Writing and Seeing: Essays on Word and Image. Ed. Maria de Fátima Lambert. Amsterdam: Rodopi. 187-98.

Inwood, Michael. 1997. Heidegger. Oxford: OUP.

Lucas, John. 1998. “A Rose for the Betrayed World”. New Statesman and Society. 26 August: 38.

McDaniel, Ray. 2006. Review of The Book of the Angel. The Constant Critic. http://www.constantcritic.com/ ray_mcdaniel/the_book_of_the_angel/.

McGuckian, Medbh. 2003. Had I A Thousand Lives. Meath: Gallery Press.

2004. The Book of the Angel. Meath: Gallery Press.

Mercer-Taylor, Peter. 2000. The Life of Mendelssohn. Cambridge: CUP.

O’Grady, Thomas. 1999. Review of Shelmalier. Boston Review. Summer, 1999. http://bostonreview.net/ BR24.3/o'grady.html.

Pattison, George. 2000. The Later Heidegger. London: Routledge.

Sered, Danielle. 2002. “'By Escaping and [Leaving] a Mark’: Authority and the Writing Subject of the Poetry of Medbh McGuckian”. Irish University Review. 32.2. Autumn-Winter: 273-85.

Skloot, Floyd. 2004. “Tracking the Muse”. Notre Dame Review. 17. Winter: 150-6.

Taplin, Oliver, ed. 2000. Literature in the Greek and Roman World: New Perspectives. Oxford: OUP.

Young, Julian. 2001. Heidegger's Philosophy of Art. Cambridge: CUP. 